\title{
Effects of Protease Inhibitors on the Autolysis and Protease Activities of Antartic Krill
}

\author{
Yukio Kawamura, Kimio Nishimura, Teruyoshi Matoba \\ and Daizo Yonezawa* \\ Research Institute for Food Science, Kyoto University, \\ Uji, Kyoto 611, Japan \\ Received August 24, 1983
}

\begin{abstract}
In order to determine which proteases are responsible for the autolysis of krill, the effects of several protease inhibitors on the autolysis and protease activities of krill were investigated.

Homogenates of whole bodies, and the cephalothorax and abdomen parts of frozen krill were equilibrated at $37^{\circ} \mathrm{C}$ at different pHs between 2 to 10 and allowed to stand for $16 \mathrm{hr}$, following which the increase in the TCA soluble fraction was monitored. ${ }^{14} \mathrm{C}-\mathrm{Hemoglobin}\left({ }^{14} \mathrm{C}-\mathrm{Hb}\right)$ hydrolyzing activity was also measured using each homogenate as a crude enzyme preparation. The degree of autolysis and the ${ }^{14} \mathrm{C}-\mathrm{Hb}$ hydrolyzing activity were maximum at $\mathrm{pH} 5 \sim 8$ for the parts studied. The hydrolytic activity was highest in the cephalothorax, followed by that in the whole body and then the abdomen.

The effects of inhibitors on the ${ }^{14} \mathrm{C}-\mathrm{Hb}$ hydrolyzing activity were examined, and it was seen that soybean trypsin inhibitor (STI), diisopropyl fluorophosphate (DFP) and leupeptin significantly inhibited the activity at neutral $\mathrm{pH}$, and pepstatin, monoiodoacetic acid (IAAcid) and leupeptin were effective at acidic $\mathrm{pH}$ for all the parts. Investigation of the effects of inhibitors on the autolysis at $20^{\circ} \mathrm{C}$ at $\mathrm{pH} 4$ and 7 by SDS-polyacrylamide gel electrophoresis indicated that the autolysis of the cephalothorax and whole body at $\mathrm{pH} 7$ was suppressed a little by STI and the autolysis of the abdomen and whole body at $\mathrm{pH} 4$ was significantly inhibited by iodoacetamide (IAA) and leupeptin.
\end{abstract}

These results suggest that the main proteases responsible for the autolysis of krill are trypsin like-proteases at neutral $\mathrm{pH}$ and cathepsins (B, $\mathrm{H}$ and $\mathrm{L}$ types) at acidic $\mathrm{pH}$.

We reported the general features of the autolysis after thawing of frozen krill in the previous paper, ${ }^{1)}$ in which it was clarified that the autolysis of krill protein was very rapid and extensive even in the intact (unfragile) state, and that among muscle proteins, myosin heavy chain was degraded very much. Since the rapid autolysis of krill proteins by endogenous proteases reduces the availability of krill as a protein food, a method to prevent the autolysis of krill has to be developed. For this, it is necessary to know the proteases involved in the autolysis.

As far as krill proteases are concerned, a protease which was affected by soybean trypsin inhibitor was separated by Noguchi et al. ${ }^{2)}$ and Seki et al. ${ }^{3)}$ Kimoto et $a .^{4)}$ recognized three kinds of proteases which were purified by ion exchange chromatography. We also reported that carboxypeptidases $\mathrm{A}$ and $\mathrm{B}$, aminopeptidase, trypsin and cathepsin A types of proteases were at least present in krill. $^{5)}$ It remains, however, unclear what kinds of proteases are present and to what extent they are involved in the autolysis.

In the present study, in order to determine the proteases responsible for the autolysis, the effects of several protease inhibitors on the

* Present Address: Department of Food Science, Faculty of Home Economics, Mukogawa Women's University, Nishinomiya, Hyogo 633, Japan.

Abbreviations: DFP, diisopropyl fluorophosphate; EDTA, ethylenediamine tetraacetic acid; Hb, hemoglobin; IAA, iodoacetamide; IAAcid, monoiodoacetic acid; 2-ME, 2-mercaptoethanol; SDS-PAGE, sodium dodecyl sulfatepolyacrylamide gel electrophoresis; STI, soybean trypsin inhibitor. 
autolysis and protease activities of krill were investigated. In general, it seems that endoproteases play a role in the autolysis which has a detrimental effect on the physicochemical properties of krill proteins. Therefore, we have mainly investigated the action of endoproteases during the autolysis.

\section{MATERIALS AND METHODS}

Materials. Antarctic krill was caught in January 1979, and frozen at $-20^{\circ} \mathrm{C}$ immediately after being caught. It was brought to the laboratory in March 1979, and stored at $-80^{\circ} \mathrm{C}$ until used. ${ }^{14} \mathrm{C}-\mathrm{Hb}$ was prepared from $\mathrm{Hb}$ (Sigma) according to the method of Williams and Lin. ${ }^{6)}$ Pepstatin, leupeptin and 2-ME were obtained from the Protein Research Foundation. DFP, IAAcid and STI were from Sigma, IAA from Nakarai Chemical Co., Ltd, and $[\mathrm{U}]-{ }^{14} \mathrm{C}$-Gly from the Radiochemical Centre. The standard proteins used for molecular weight estimation by SDS-PAGE were lyzozyme from Sigma, bovine serum albumin and aldolase from Boehringer and $\gamma$-globulin from Povite.

Measurement of autolysis. About $5 \mathrm{~g}$ of frozen whole bodies, cephalothorax and abdomen parts was homogenized at $0^{\circ} \mathrm{C}$ in $5 \mathrm{vol} .(\mathrm{v} / \mathrm{w})$ of buffer, which contained $0.1 \mathrm{M}$ $\mathrm{CH}_{3} \mathrm{COONa}, 0.05 \mathrm{M} \mathrm{NaHCO}$ and $\mathrm{Na}_{2} \mathrm{CO}_{3}, 0.1 \mathrm{M} \mathrm{KCl}$ and $0.001 \% \mathrm{NaN}_{3}$, and was adjusted to the desired $\mathrm{pH}$ with $1 \mathrm{~N} \mathrm{HCl}$ or $\mathrm{NaOH}$. After the $\mathrm{pH}$ of the homogenates was readjusted, they were incubated for $16 \mathrm{hr}$ at $37^{\circ} \mathrm{C}$. An equal amount of $10 \%$ TCA solution was added to the incubation mixture to terminate the autolysis. After centrifugation, $20 \sim 100 \mu$ l of the supernatant was used for the determination of ninhydrin positive materials $(\mathrm{NPM})^{7)}$ and folin positive materials (FPM) ${ }^{8)}$

Measurement of protease activities. Protease activity in the krill homogenates was determined with ${ }^{14} \mathrm{C}-\mathrm{Hb}$ at $37^{\circ} \mathrm{C}$ and various $\mathrm{pHs}$ for $1 \mathrm{hr}$. The incubation mixture $(750 \mu \mathrm{l})$ contained $500 \mu \mathrm{l}$ of the buffer, $50 \sim 100 \mu \mathrm{l}$ of krill homogenate, $25 \mu \mathrm{l}$ of ${ }^{14} \mathrm{C}-\mathrm{Hb}(0.625 \mathrm{mg} / \mathrm{ml}, 3000 \mathrm{cpm})$ and an appropriate amount of distilled water. The buffer contained $0.1 \mathrm{M}$ tricine, $0.1 \mathrm{M}$ borate and $0.1 \mathrm{~m}$ acetate, and was adjusted to the desired $\mathrm{pH}$ with $1 \mathrm{~N} \mathrm{HCl}$ or $\mathrm{NaOH}$. The reaction was stopped by the addition of $500 \mu \mathrm{l}$ of $15 \%$ TCA solution after $250 \mu \mathrm{l}$ of $4 \%$ cold $\mathrm{Hb}$ was added. After centrifugation, $1 \mathrm{ml}$ of the supernatant was added to $5 \mathrm{ml}$ of Bray's solution ${ }^{9)}$ and subjected to radioactivity determination with a Packard Tri-carb spectrophotometer. Under these experimental conditions, the activity of $1000 \mathrm{cpm} / \mathrm{min}$ corresponded to $7.38 \times 10^{-3}$ units of pepsin (Sigma).

SDS-PAGE analysis. The krill autolyzates after in- cubation at $20^{\circ} \mathrm{C}$ were mixed with an equal vol. (v/v) of $0.125 \mathrm{M}$ Tris- $\mathrm{HCl}$ buffer, $\mathrm{pH} 6.8$, containing $4 \%$ SDS, $10 \%$ 2-ME and $20 \%$ glycerol. After heating at $100 \%$ for $5 \mathrm{~min}$, the mixture $(20 \sim 100 \mu \mathrm{l})$ was subjected to SDS-PAGE. SDS-PAGE was carried out on a slab gel $(1 \times 130 \times$ $120 \mathrm{~mm}$ ) at $20 \mathrm{~mA}$ for $3 \sim 4 \mathrm{hr}$ by using the discontinuous buffer system of Laemmli. ${ }^{10)}$ After being stained with $0.1 \%$ Commassie blue R-250 in methanol-water-acetic acid solution $(5: 4: 1, \mathrm{v} / \mathrm{v})$ for $20 \mathrm{~min}$, the gel was destained in water-methanol-acetic acid solution $(83: 10: 7, \mathrm{v} / \mathrm{v})$ with continuous shaking. The destained gel was dried on a filter paper and subjected to densitometric determination with a Shimadzu Dual-wavelength TLC scanner CS-90 at a reference wavelength of $750 \mathrm{~nm}$ and a sample wavelength of $590 \mathrm{~nm}$.

\section{RESULTS AND DISCUSSION}

\section{pH-Dependence of autolysis}

Homogenates of whole bodies, and cephalothorax and abdomen parts of frozen krill were allowed to stand at $\mathrm{pHs}$ between 2 to 10 at $37^{\circ} \mathrm{C}$ for $16 \mathrm{hr}$. The increases of TCA soluble NPM and FPM were determined, to investigate mainly the actions of exo-proteases and endo-proteases, respectively.

Figure 1A shows the $\mathrm{pH}-$ dependent production of NPM. NPM was produced mostly at $\mathrm{pH} 5 \sim 6$ in all the three homogenates. The amount of NPM liberated at $\mathrm{pH} 6$ in the cephalothorax homogenate was about twice as much as in the whole body homogenate, while that in the abdomen homogenate was very little. The liberation of NPM in the cephalothorax and whole body homogenates decreased sharply below $\mathrm{pH} 5$, but slowly over $\mathrm{pH}$ 6. These results suggest that the action of exo-proteases of krill was extensive in the cephalothorax. Figure 1B shows the $\mathrm{pH}-$ dependent production of FPM. In contrast to the production of NPM, FPM was liberated in two peaks, at pH 5 and around or over $\mathrm{pH} 10$. The FPM at pH 5 was mostly in the whole body homogenate followed those of the abdomen and cephalothorax in that order, showing that the action of endo-proteases may be strong in all the parts. A considerable amount of FPM was produced over $\mathrm{pH} \mathrm{9,} \mathrm{but} \mathrm{TCA}$ soluble supernatants of the homogenates at $\mathrm{pH} 9$ and 10 showed lower absorbance at $280 \mathrm{~nm}$ compared to that at lower $\mathrm{pH}$. 

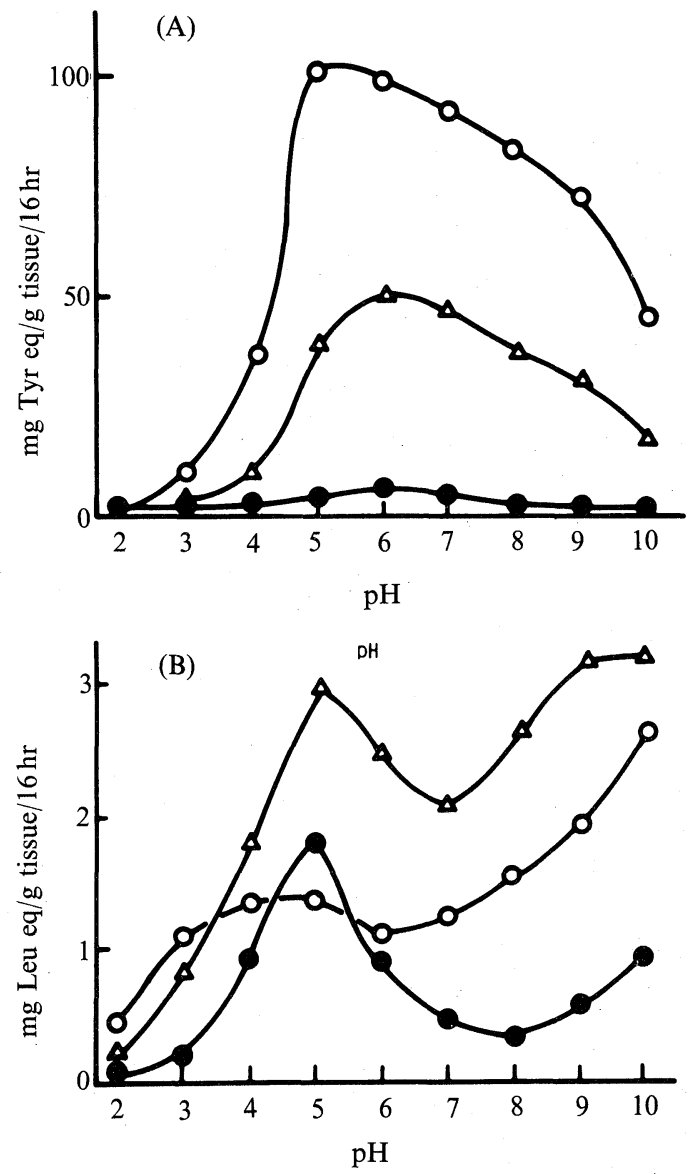

FIG. 1. pH-Dependence of Autolysis.

The homogenate of each part of krill was adjusted to the desired $\mathrm{pH}$, and incubated for $16 \mathrm{hr}$ at $37^{\circ} \mathrm{C}$. An equal amount of $10 \%$ TCA solution was added to the incubation mixture to terminate the autolysis. After centrifugation, the determination of NPM (A) and FPM (B) were carried out. $\triangle-\triangle$, whole body; $\bigcirc-O$, cephalothorax; abdomen.

Therefore, this peak $(\mathrm{pH}>9)$ may be due to hydrolysate of nucleic acid.

\section{pH-Dependence of protease activity of krill homogenates}

Each part of frozen krill (cephalothorax, abdomen and whole body) was homogenized in $5 \mathrm{vol}$. of buffer at various pHs between $2 \sim 10$, as described in MATERIALS AND METHODS. The protease activity was measured using ${ }^{14} \mathrm{C}-\mathrm{Hb}$ as substrate to avoid the action of proteases for endogenous proteins of krill. The results are shown in Fig. $2 .{ }^{14} \mathrm{C}-\mathrm{Hb}$ was

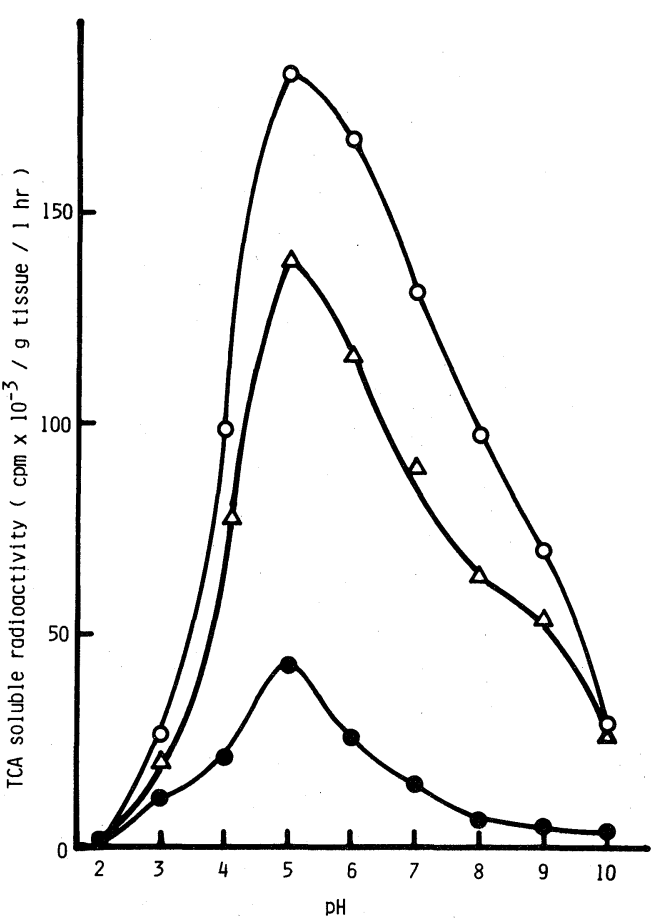

FIG. 2. pH-Dependence of Protease Activity of Krill Homogenates.

Protease activity in the krill homogenates was deter mined with ${ }^{14} \mathrm{C}-\mathrm{Hb}$ at $37^{\circ} \mathrm{C}$ and various $\mathrm{pHs}$ for $1 \mathrm{hr}$. Symbols are the same as in Fig. 1.

hydrolyzed optimumly at $\mathrm{pH} 5$ by the three homogenates. The ${ }^{14} \mathrm{C}-\mathrm{Hb}$ hydrolyzing activity was much higher in the cephalothorax than in the abdomen. The activity in the whole body showed an intermediary value. When the activity at $\mathrm{pH} 5$ in the cephalothorax homogenate was taken as $100 \%$, those in the abdomen and whole body homogenates were 22 and $72 \%$, respectively. The relative activity at $\mathrm{pH} 7$ to $\mathrm{pH} 5$ was about $70 \%$ in the cephalothorax homogenate, $38 \%$ in the abdomen homogenate and $64 \%$ in the whole body homogenate.

\section{Effects of protease inhibitors on protease activity}

In order to determine the types of protease involved in the ${ }^{14} \mathrm{C}$-Hb hydrolyzing activity in the krill homogenates, the effects of pepstatin, STI, DFP, IAAcid, leupeptin and EDTA plus 

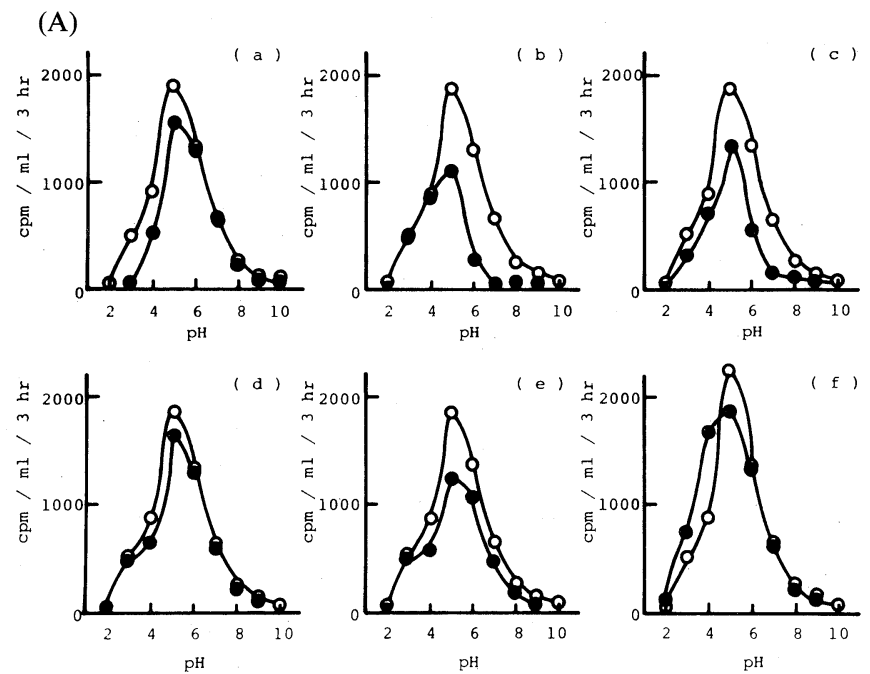

(B)
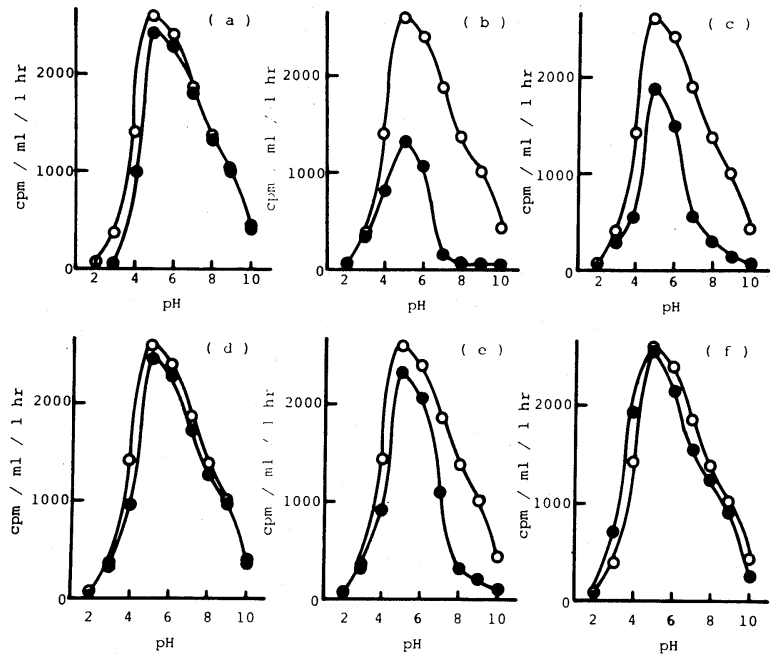

(C)
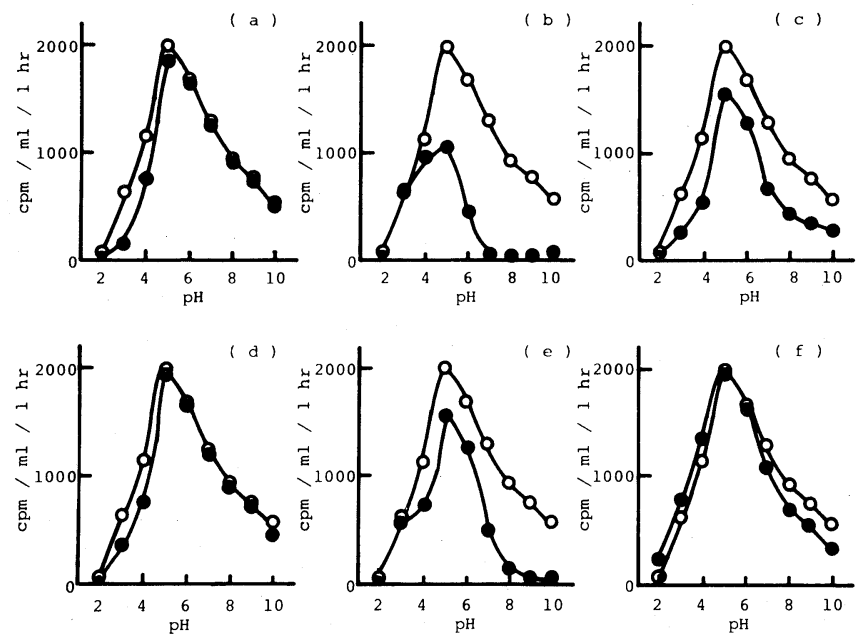

FIG. 3. 
2-ME on the protease activity were investigated at pHs between $\mathrm{pH} 2$ to 10 , as described in Materials AND Methods.

Figure $3 \mathrm{~A}$ shows the results regarding the abdomen homogenate. The main enzymes working in the abdomen are probably intracellular proteases such as cathepsins. Pepstatin inhibited the activity below pH 5 but not that over $\mathrm{pH} 6$. The rate of inhibition was $20 \%$ at $\mathrm{pH} 5,40 \%$ at $\mathrm{pH} 4$ and $85 \%$ at $\mathrm{pH} 3$. This shows that cathepsin D was active at acidic pH. STI markedly inhibited the activity over $\mathrm{pH} 5$. The rate of inhibition was $45 \%$ at $\mathrm{pH} 5,80 \%$ at $\mathrm{pH} 6$ and $100 \%$ over $\mathrm{pH} 7$. DFP showed effective inhibition above $\mathrm{pH} 6$ and some inhibition below $\mathrm{pH} 5(30 \%$ at $\mathrm{pH} 5$, $40 \%$ at $\mathrm{pH} 4$ and $30 \%$ at $\mathrm{pH} 3$ ).

The inhibition by STI and DFP indicates that trypsin-like proteases (serine-proteases) were active at $\mathrm{pHs}$ between $\mathrm{pH} 5$ to 8 . In general, this type of enzyme (more active around $\mathrm{pH}$ 8) is known to be present in the digestive organs. Therefore, the present trypsin-like proteases may be different from the enzymes of the digestive organs, since the abdomen (muscle part) was separated from the cephalothorax (digestive organ part). Sanada et al ${ }^{11)}$ and Murakami et al. ${ }^{12)}$ reported the existence of serine-proteases in the rat myofibrillar fraction. Noguchi et al. ${ }^{2)}$ and Seki et al. ${ }^{3)}$ separated trypsin-like proteases having optimum activities at $\mathrm{pH} 6$ and $\mathrm{pH} 8$, respectively. Kimoto et al. ${ }^{4)}$ purified ones having optimum activities at $\mathrm{pH} 8$ from whole bodies of krill, showing that three types of trypsin-like proteases are present in krill. However, the localization of these enzymes (abdomen and/or cephalothorax) is not yet clear.

Leupeptin showed some inhibition over the wide $\mathrm{pH}$ range and showed maximum inhibition $(40 \%)$ at $\mathrm{pH}$. EDTA plus 2-ME showed a stimulating effect on the activity below $\mathrm{pH}$ 5. The rate of stimulation of the activity was $20 \%$ at $\mathrm{pH} 5,100 \%$ at $\mathrm{pH} 4$ and $50 \%$ at $\mathrm{pH} 3$. The $\mathrm{pH}$-activity curve in the presence of IAAcid $(1 \mathrm{ml})$ was similar to that of leupeptin. This observation shows that $\mathrm{SH}$ proteases such as cathepsin $\mathrm{B}, \mathrm{H}$ and $\mathrm{L}^{13 \sim 17)}$ were active at acidic $\mathrm{pH}$.

Figure 3-B shows the results for the cephalothorax homogenate. The main enzymes acting in the cephalothorax were probably derived from the digestive organs. The results were generally similar to the results for $a b-$ domen homogenates (Fig. 3A). That is, the protease activity above $\mathrm{pH} 6$ was inhibited by STI, DFP and leupeptin, and that below pH 5 by pepstatin, DFP and leupeptin. STI showed stronger inhibitory effects between $\mathrm{pH} 4$ and 10 than seen in the abdomen. These results show that serine-proteases such as trypsin and chymotrypsin-like enzymes were active above $\mathrm{pH} 6$, and pepsin-like proteases were active below $\mathrm{pH}$ 4. The stronger inhibition around pH 6 by STI (Fig. 3B (b)) suggests that the present trypsin-like proteases having optimum activities in this $\mathrm{pH}$ region were of the same type as those reported by Noguchi et al. ${ }^{2)}$ The complete inhibition at pH 8 by STI (Fig. 3B (b)) may indicate that the trypsin-like proteases purified by Kimoto et $a l^{4)}$ were present in the cephalothorax. We mainly investigated proteases from the digestive organs, but the action of intracellular proteases from the tissues of the organs, as described in Fig. 3-A, may not be negligible in the cephalothorax.

Leupeptin did not inhibit the activity at $\mathrm{pH}$ 5 so much as shown in Fig. 3A. Inhibition of the activity at $\mathrm{pH} 5$ and 4 by pepstatin was more than that in the abdomen homogenates (Fig. 3-A). The activation by EDTA plus 2$\mathrm{ME}$ below $\mathrm{pH} 5$ was not as significant as that

\section{FIG. 3. Effects of Protease Inhibitors on Protease Activity.}

Protease activity of the krill homogenates was determined at between $\mathrm{pH} 2$ and 10 in the presence of various inhibitors. Preincubation was carried out at $0^{\circ} \mathrm{C}$ for $1 \mathrm{hr}$. Concentrations of the inhibitors used were as follows: (a), pepstatin (1.5 × 10 $\left.0^{-5} \mathrm{M}\right)$; (b), STI (0.05\%); (c), DFP (2 mM); (d), IAAcid (2 mM); (e), leupeptin (1 $\times$ $\left.10^{-5} \mathrm{M}\right)$; and (f), EDTA ( $2 \mathrm{mM}$ ) plus 2-ME (2 mM). (A), abdomen homogenate; (B) cephalothorax homogenate; $(C)$, whole body homogenate, $\bigcirc-\bigcirc$, homogenate without inhibitors; $-\mathrm{O}$, homogenate with inhibitors. 
(A)

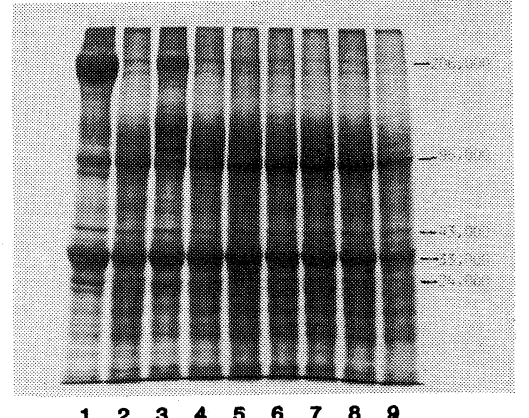

$\begin{array}{llllllllll}1 & 2 & 3 & 4 & 5 & 6 & 7 & 8 & 8\end{array}$

\section{(D)}

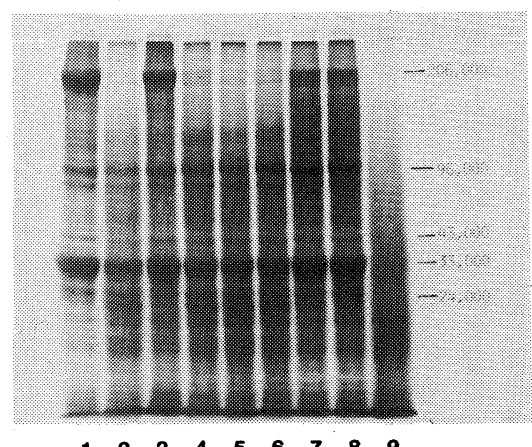

( B )

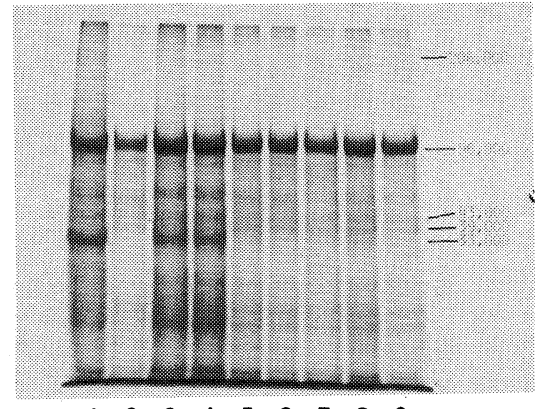

$\begin{array}{lllllllllll}1 & 2 & 3 & 4 & 5 & 6 & 7 & 8 & 9\end{array}$

( $E$ )

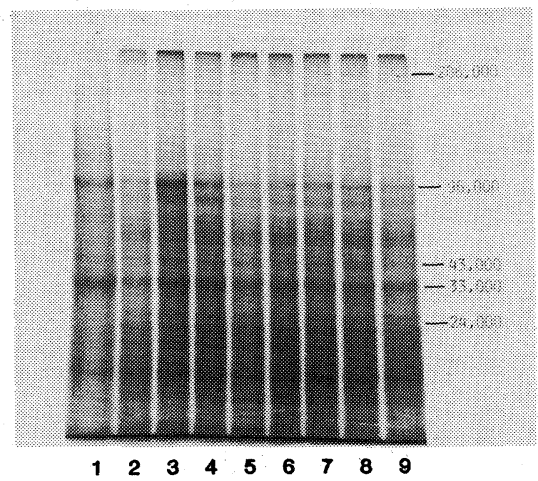

(C)

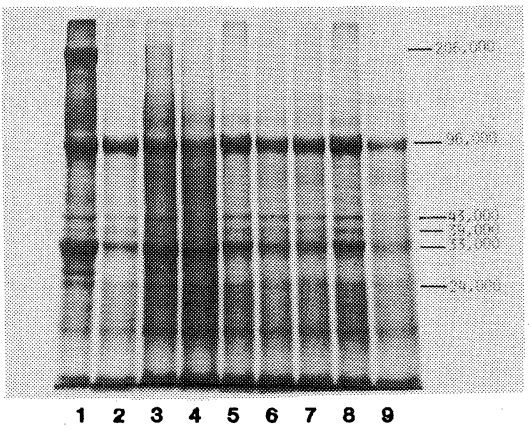

(F)

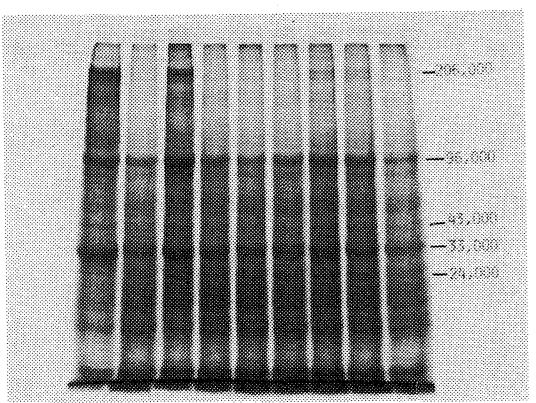

$\begin{array}{llllllllll}1 & 2 & 3 & 4 & 5 & 6 & 7 & 8 & 9\end{array}$

FIG. 4. Effects of Protease Inhibitors on Autolysis.

Homogenates of abdomen, cephalothorax and whole body were incubated at $\mathrm{pH} 4$ and $20^{\circ} \mathrm{C}$ for 8,2 and $2 \mathrm{hr}$, respectively, or at $\mathrm{pH} 7$ and $20^{\circ} \mathrm{C}$ for 12,3 and $4 \mathrm{hr}$, respectively, in the presence of various inhibitors, and were then subjected to SDS-PAGE. Preincubation was carried out at $0^{\circ} \mathrm{C}$ for $1 \mathrm{hr}$. Concentrations of the inhibitors used were as follows: (4), STI (0.05\%); (5), DFP (1 mM); (6), pepstatin $\left(1 \times 10^{-5} \mathrm{M}\right)$; (7), IAA $(1 \mathrm{mM})$; (8), leupeptin $\left(1 \times 10^{-5} \mathrm{M}\right)$; (9), EDTA $(1 \mathrm{mM})$ plus 2-ME $(2 \mathrm{mM})$. (1), (2) and (3) are the control (at $\left.0 \mathrm{hr}\right)$, no inhibitors and addition of all inhibitors, samples respectively. (A), abdomen homogenate at $\mathrm{pH} 7$; (B), cephalothorax homogenate at $\mathrm{pH} 7$; (C), whole body homogenate at $\mathrm{pH} 7$; (D), abdomen homogenate at $\mathrm{pH} 4$; (E), cephalothorax homogenate at $\mathrm{pH} 4$; (F), whole body homogenate at $\mathrm{pH} 4$. 
in the abdomen.

Figure $3 \mathrm{C}$ shows the results for the whole homogenates. Basically, the inhibition profile for each inhibitor was similar to those in the abdomen and cephalothorax, though the degree of inhibition was slightly different.

\section{Effects of protease inhibitors of autolysis}

Homogenates of abdomen, cephalothorax and whole body were incubated at $\mathrm{pH} 4$ and $20^{\circ} \mathrm{C}$ for 8,2 and $2 \mathrm{hr}$, respectively, or at $\mathrm{pH} 7$ and $20^{\circ} \mathrm{C}$ for 12,3 and $4 \mathrm{hr}$, respectively, in the presence of various inhibitors. Effects of the inhibitors on the autolysis of krill proteins were studied by SDS-PAGE.

Figures $4 \mathrm{~A}$ and $\mathrm{D}$ show the results for the abdomen homogenates at $\mathrm{pH} 7$ and 4, respectively. At pH 7 (Fig. 4A), when the SDSPAGE patterns of the $0 \mathrm{hr}$ control (no autolysis) (1) and the sample containing no inhibitor (2) were compared, the disappearance of the bands of MW $=206,000$ (probably myosin heavy chain) and 88,000 components was significant, over $90 \%$ as judged by densitometric determination. The disappearance of bands of $\mathrm{MW}=96,000$ and 33,000 components was 39 and $35 \%$, respectively. The individual addition of STI (4), DFP (5), pepstatin (6), IAA (7) and leupeptin (8) did not cause decreases of these bands, but on addition of all inhibitors (STI, DFP, pepstatin, IAA, leupeptin and EDTA) (3) about $60 \%$ of the $\mathrm{MW}=$ 206,000 band and $40 \%$ of the $\mathrm{MW}=88,000$ band remained unhydrolyzed. These results suggest that a particular protease as described in Fig. 3A did not participate in the autolysis of the muscle part of krill at neutral $\mathrm{pH}$.

At $\mathrm{pH} 4$ (Fig. 4D), comparison of the SDSPAGE patterns of the $0 \mathrm{hr}$ control (1) and no inhibitor (2) samples showed that the disappearance of the $\mathrm{MW}=206,000$ band was most significant. The percentages of degradations of the main bands of $\mathrm{MW}=206,000,96,000$ and 33,000 components were about 95,65 , and $50 \%$, respectively. The addition of IAA (7) and leupeptin (8) alone prevented the autolysis. The percentages of degradation of $\mathrm{MW}=$ 206,000, 96,000 and 33,000 components were reduced to about 35,8 and $10 \%$ by the addition of IAA (7) and leupeptin (8) alone. These observation strongly suggest that the action of SH-type intracellular proteases such as cathepsins $\mathrm{B}, \mathrm{H}$ and $\mathrm{L}$, which was expected in Fig. 3A, played an important role in the autolysis of the muscle part at acidic $\mathrm{pH}$.

The addition of STI, DFP and pepstatin alone was not as effective as IAA and leupeptin, as far as the disappearance of the $\mathrm{MW}=$ 206,000 band was concerned. In the presence of all inhibitors, the disappearance of the bands of $\mathrm{MW}=206,000,96,000$ and 33,000 components was less than $10 \%$. The addition of EDTA plus 2-ME stimulated the autolysis. This stimulation of the autolysis was certainly due to the activation of SH-type proteases by the reducing reagent as described above.

Figures $4 \mathrm{~B}$ and $\mathrm{E}$ show the results for the cephalothorax homogenates at $\mathrm{pH} 7$ and 4, respectively. At $\mathrm{pH} 7$ (Fig. 4B), the $\mathrm{MW}=$ 33,000 band disappeared completely in the absence of inhibitors, while the $\mathrm{MW}=96,000$ band did not change significantly. The addition of STI (4) prevented the degradation of the $\mathrm{MW}=33,000$ band by about $70 \%$ and the effectiveness was similar to that of the mixture of all inhibitors. These results show that the action of trypsin-like proteases was extensive in the cephalothorax autolysis at neutral $\mathrm{pH}$ as indicated in Fig. 3B. At pH 4 (Fig. 4E), only STI prevented the autolysis slightly, the other inhibitors did not prevent degradation of the bands at all.

Figures $4 \mathrm{C}$ and $\mathrm{F}$ show the results regarding the whole body homogenates at $\mathrm{pH} 7$ and 4 , respectively. At pH 7 (Fig. 4C), in the absence of inhibitors, the bands of $\mathrm{MW}=206,000$ and 24,000 components disappeared completely, and the $\mathrm{MW}=33,000$ band was degraded by about $70 \%$. The $\mathrm{MW}=96,000$ band was not significantly changed, DFP and leupeptin being only slightly effective in preventing degradation of the $\mathrm{MW}=96,000$ band. STI (4) was slightly effective in protecting the $\mathrm{MW}=$ 33,000 band. Pepstatin and IAA had no effect on the autolysis. Even on the addition of all inhibitors (3), the degradation of each protein, 
as seen on SDS-PAGE, was not completely suppressed. This was especially true for the $\mathrm{MW}=206,000$ component (probably myosin heavy chain) which may affect physicochemical properties of krill protein. These results suggest that the protease in the cephalothorax acts strongly in the autolysis of the muscle part of krill at neutral $\mathrm{pH}$.

At pH 4 (Fig. 4F), leupeptin (8) and IAA (7) prevented the autolysis slightly, showing that the action of SH-type cathepsins described above was suppressed, but the other inhibitors did not affect the degradation.

From the above results, it appears that the separation of the abdomen and cephalothorax from krill is important for maintaining the physicochemical quality of krill proteins for adequate utilization as foodstuffs.

\section{REFERENCES}

1) Y. Kawamura, K. Nishimura, S. Igarashi, E. Doi and D. Yonezawa, Agric. Biol. Chem., 45, 93 (1981).

2) A. Noguchi, M. Yanagimoto, K. Umeda and S. Kimura, Nippon Nôgeikagaku Kaishi, 50, 415 (1976).

3) N. Seki, H. Sakaya and T. Onozawa, Bull. Japan Soc.
Sci. Fish., 43, 955 (1977).

4) K. Kimoto, S. Kusama and K. Murakami, Agric. Biol. Chem., 47, 529 (1983).

5) K. Nishimura, Y. Kawamura, T. Matoba and D. Yonezawa, Agric. Biol. Chem., 47, 2577 (1983).

6) H. R. Williams and T. Y. Lin, Biochim. Biophys. Acta, 250, 603 (1971).

7) S. Moore and W. H. Stein, J. Biol. Chem., 211, 907 (1954).

8) O. H. Lowry, N. J. Rosebrough, A. L. Farr and R. J. Randall, J. Biol. Chem., 193, 265 (1951).

9) G. A. Bray, Anal. Biochem., 1, 279 (1960).

10) U. K. Laemmli, Nature, 227, 680 (1970).

11) Y. Sanada, N. Yasogawa and N. Katunuma, $J$. Biochem., 85, 481 (1979).

12) U. Murakami and K. Uchida, J. Biochem., 86, 553 (1979).

13) H. Kirschke, J. Langner, B. Wiederanders, S. Ansorge, P. Bohley and H. Hanson, Acta Biol. Med. Germ., 36, 185 (1977).

14) H. Kirschke, J. Langner, B. Wiederanders, S. Ansorge and P. Bohley, Eur. J. Biochem., 74, 293 (1977).

15) J. F. Lenney, J. R. Tolan, W. J. Sugai and A. G. Lee, Eur. J. Biochem., 101, 153 (1979).

16) T. Towatari, Y. Kawabata and N. Katunuma, Eur. J. Biochem., 102, 279 (1979)

17) A. Okitani, U. Matsukura, H. Kato and M. Fujimaki, J. Biochem., 87, 1133 (1980) 